\title{
Influences of dietary crude protein and stocking density on growth performance and body measurements of ostrich chicks
}

\author{
KHALID M. MAHROSE ${ }^{1}$, MOHAMED E. ABD EL-HACK ${ }^{1}$ and SHYMAA A. AMER ${ }^{2}$ \\ ${ }^{1}$ Poultry Department, Faculty of Agriculture, Zagazig University, Zagazig 44511, Egypt \\ ${ }^{2}$ Nutrition and Clinical Nutrition Department, Faculty of Veterinary Medicine, Zagazig University, Zagazig 44511, Egypt \\ Manuscript received on May 16, 2018; accepted for publication on July 9, 2018
}

\begin{abstract}
How to cite: MAHROSE KM, ABD EL-HACK ME AND AMER SA. 2019. Influences of dietary crude protein and stocking density on growth performance and body measurements of ostrich chicks. An Acad Bras Cienc 91: e20180479. DOI 10.1590/0001-3765201920180479.
\end{abstract}

\begin{abstract}
Thirty-six African Black ostrich chicks were used to investigate the effects of dietary crude protein (CP) levels (180, 210 and $240 \mathrm{~g} / \mathrm{kg})$, stocking density (4.5 and $\left.3 \mathrm{~m}^{2} / \mathrm{bird}\right)$ and their interactions. A factorial arrangement was used to examine the impact of treatments on growth performance and body measurements of ostrich chicks during 2 to 10 weeks of the age. Results indicated that factors studied did not change growth performance traits. The highest value of protein efficiency ratio was observed in ostrich chicks fed diet contained $240 \mathrm{~g} / \mathrm{kg}$ diet. Birds fed diet contained $240 \mathrm{~g} \mathrm{CP} / \mathrm{kg}$ diet and kept at stocking density of $3 \mathrm{~m}^{2}$ per bird had numerically the highest protein efficiency ratio. Shank girth and tibiotarsus length decreased with increasing dietary CP level. Stocking density did not change values of body measurements, except tibiotarsus length at 6 weeks of age, which increased in birds kept at the lower density than the higher. Body height at 10 weeks of age was significantly affected by the interactions between dietary $\mathrm{CP}$ and stocking density. In conclusion, results affirmed that ostrich chicks can grow on diets containing low levels of CP $(180-210 \mathrm{~g} / \mathrm{kg})$. Our results provide a comprehensive set of morphometric data for ostrich chicks as affected by the factors studied.
\end{abstract}

Key words: Crude Protein, stocking density, growth, body measurements, ostrich.

\section{INTRODUCTION}

The fast increase in human population caused a continuous need for the increment of food resources, especially high-protein products like meat. This has increased per capita consumption of chicken, and thus, commercial farming has expanded to ostrich and it is increasing rapidly (Laudadio and Tufarelli 2011, Bouyeh et al. 2017). Recent

Correspondence to: Mohamed E. Abd El-Hack

E-mail: m.ezzat@zu.edu.eg /

dr.mohamed.e.abdalhaq@gmail.com

ORCid: https://orcid.org/0000-0002-2831-8534 interest in ostrich farming has led to an increase in the demand for information about this bird and how to manage it in the commercial farms (Minka 2004, Cooper et al. 2008, El-Safty and Mahrose 2009, Mahrose et al. 2016). To maximize profit, the ostrich industry must focus on increasing chick survivability, maximizing growth and reducing costs associated with feeding (Cornetto et al. 2003, Bouyeh et al. 2017). The factors affecting growth in ostriches are similar to those affecting other avian species and include diet, rearing environment, genetic potential, management and health status. Literature on ostrich nutrition and available space 
is limited, particularly those pertaining to the earlylife stage (Iji 2005, Mahrose et al. 2015, Sigolo et al. 2017, Vahabi-Asil et al. 2017).

Stocking density needed by ostrich chicks depends on the type of housing. Semi-intensive rearing of birds is the most widely used method and even during intensive keeping of ostriches in controlled environment houses it is advisable to let them out to minimize occurrence of leg problems (du Preez 1991). The aforementioned author added that the values of stocking density of broilers should not be directly applied to ostrich chicks. Providing adequate space to ostrich chicks could help diminish stress and consequently lead to improving survivability and growth rate (Cornetto et al. 2003). Ostrich chicks are raised under a wide range of stocking densities, ranging from 16 to 40 $\mathrm{m}^{2}$ per bird (Verwoerd 1999).

However, the development of ostrich industry is hampered by inadequate knowledge of nutritional requirements of this species, particularly those pertaining to the early-life stage (Iji 2005). Nutrition is an important part of poultry and ratite management. So, knowledge of nutrient needs during the various stages of growth, development and production of the ostrich is vital (Cooper et al. 2005). Nutrition of ostrich chicks must be correct, as they are most vulnerable up to the age of 3 months (Cooper 2004). In order to increase profitability of ostriches, determination of nutrient requirements of ostriches is essential (Cilliers et al. 1998). The inclusion of protein in feeds needs to be optimized for optimum performance as well as to minimize wastage (Ahmed et al. 2011). Ostriches require rations with high protein content, which is an essential nutrient for optimum growth and development (Cooper 2004). Feeding costs are the largest expense in an ostrich production system, and protein is one of the most expensive components of the diet (Carstens et al. 2014). Diverse recommendations concerning the protein content in starter diets $(14.6-22 \% \mathrm{CP})$ of ostriches have been reported. Most ratite growers feed diets that contain $17-24 \%$ crude protein during brooding and growing (Cilliers 1998). The protein deficiency, caused by either one or more limiting amino acids or an overall inadequate consumption of protein, will result in decreases in parameters such as growth rate, $\mathrm{N}$ retention, feed consumption and utilization (Reda et al. 2015). However, an over-consumption of protein results in the catabolism of amino acids through deamination and excretion as uric acid, which is both energetically and economically inefficient or in severe cases, ammonia toxicity (Alagawany et al. 2016a, b). It is essential to try to meet the requirement of poultry as closely as possible in order to maximize production and profitability (Alagawany et al. 2014, Rehman et al. 2018).

The present study aimed at investigating the effects of stocking density and dietary crude protein levels on growth performance and body measurements of ostrich chicks during 2-10 weeks of age.

\section{MATERIALS AND METHODS}

The present work was carried out at the Ostrich farm, Faculty of Agriculture, Zagazig University, Zagazig city, Egypt. All experimental procedures were carried out according to the Local Experimental Animal Care Committee, and approved by the ethics of the institutional committee of the Department of Poultry, Faculty of Agriculture, Zagazig University, Zagazig, Egypt.

\section{BIRDS, EXPERIMENTAL DESIGN AND DIETS}

Thirty-six African Black unsexed ostrich chicks were allotted into 6 groups ( 6 chicks per group; each group had three sub-groups of equal numbers; 2 birds each) in factorial arrangement $(3 \times 2)$ to investigate the influences of 3 dietary protein levels $(180,210$ and $240 \mathrm{~g} / \mathrm{kg}$ ) and 2 levels of stocking density (4.5 and $3 \mathrm{~m}^{2}$ per bird) on growth performance (body weight, body weight gain, feed consumption, 
feed conversion ratio and protein efficiency ratio) of ostrich chicks during 2 to 10 weeks of age. In addition, body measurements (body height, neck length, neck diameter, thoracic girth, phalanges length, tarsometatarsus length, tarsometatarsus girth, tibiotarsus length and tibiotarsus girth) were measured at 6 and 10 weeks of age. Ingredients and composition of experimental diets of ostrich chicks are found in Table I. All diets were isocaloric.

\section{MANAGEMENT}

Unsexed ostrich chicks of 2 weeks of age were randomly divided into 6 groups (of equal average body weight). Each chick was identified by shank tag. Chicks were kept indoors until 4 weeks of age and after that, they were allowed to practice outdoors during midday and kept indoors at night. Chicks were exposed to $16: 8 \mathrm{~h}$ light/dark cycle and light intensity for all groups ranged between
24 and 50 Lux. All chicks were kept under similar managerial and hygienic conditions during the experimental period. Food was provided ad libitum to all groups during the experimental period. Fresh water was made available at all times.

\section{DATA COLLECTION AND MEASUREMENTS}

All chicks were individually weighed using an electronic balance accurate to $5 \mathrm{~g}$ and body weight was recorded at 2, 6 and 10 weeks of age. Daily body weight gain was calculated as the difference between the two successive weights and divided by the number of days. Feed consumption was weekly recorded for each group, and calculated as gram diet per bird by dividing feed consumption of the group by the number of birds in this group. Feed conversion ratio (g feed /g gain) was calculated. Protein efficiency ratio was calculated by dividing daily weight gain by protein intake.

TABLE I

Ingredients and calculated analysis of ostrich chick diets.

\begin{tabular}{cccc}
\hline Ingredients & & Crude protein (g/kg diet) \\
(g/kg as fed basis) & $\mathbf{2 1 0}$ & $\mathbf{2 4 0}$ & \\
\cline { 2 - 4 } $\mathbf{1 8 0}$ & 377 & 438 & 462 \\
\hline Yellow Corn & 360 & 313 & 190 \\
Soybean meal 44 (\%) & 26 & 0.0 & 20 \\
Gluten meal 62 (\%) & 72.5 & 94.0 & 200.0 \\
Hay & 100.0 & 89.0 & 70.0 \\
Wheat bran & 8.5 & 12.5 & 9.5 \\
Molasses & 12.5 & 10.0 & 8.0 \\
Vit-min Premix & 2.0 & 2.0 & 1.5 \\
DL Methionine & 4.0 & 4.0 & 1.5 \\
L-Lysine & 20.0 & 20.0 & 10.0 \\
Di Calcium phosphate & 15.0 & 15.0 & 25.0 \\
Limestone & 2.5 & 2.5 & 2.5 \\
NaCl & 180 & & 240 \\
\hline Calculated analysis $(\mathrm{g} / \mathrm{kg}$ as fed basis) & 10.3 & 10.4 & 10.3 \\
\hline CP (g/kg) & & 210 & \\
\hline
\end{tabular}

${ }^{\#}$ Growth vitamin and Mineral premix, each $1 \mathrm{~kg}$ consists of: Vit A 12000,000 IU/kg; Vit D , 2000,000 IU; Vit. E, 10,000 IU/kg as dl- $\alpha$-tocopheryl acetate; Vit k 2 g; Vit $B_{1}, 1000 \mathrm{mg}$; Vit $\mathrm{B}_{2}, 49 \mathrm{~g}$; Vit $\mathrm{B}_{6}, 105 \mathrm{~g}$; Vit $\mathrm{B}_{12}, 10 \mathrm{mg}$; Pantothenic acid, $10 \mathrm{~g}$; Niacin, 20 g, Folic acid, 1000 mg; Biotin, 50 g; Choline Chloride, 500 mg, Fe, 30 g; Mn, 40 g; Cu, 3 g; Co, 200 mg; Si, 100 mg and Zn, 45 g. 
Linear dimensions of the body (body height, neck length, neck diameter, thoracic girth, phalanges length, tarsometatarsus length, tarsometatarsus girth, tibiotarsus length and tibiotarsus girth) were taken twice during the experimental period (at 6 and 10 weeks of age) to the nearest $0.5 \mathrm{~cm}$ with dressmaker's flexible tape-measure and are described as follows; bird height was taken from claws to dorsal of the thorax. Thoracic girth was measured behind the shoulders at the notch in the junction between the cervical and thoracic vertebrae. Length of tibiotarsus was measured on the lateral side of the leg from the front of the patella to the back of the hock joint as described by Deeming et al. (1996). Tibiotarsus girth was taken from the mid. The length of the tarsometatarsus was measured on the caudal side of the leg from the back of the hock joint to the phalangeal joint. Tarsometatarsus girth was taken from the its mid.

\section{STATISTICAL ANALYSIS}

Data of the present study were statistically analyzed by ANOVA of $3 \times 2$ factorial design experiment. Differences between means were tested by Duncan's multiple range test at level of $\alpha=0.05$ (Duncan 1955). The statistical model used was:

$\mathrm{Y}_{\mathrm{ijk}}=\mu+\mathrm{CP}_{\mathrm{i}}+\mathrm{SD}_{\mathrm{j}}+\mathrm{CPSD}_{\mathrm{ij}}+\mathrm{e}_{\mathrm{ijk}}$

Where: $Y_{\mathrm{ijk}}=$ an observation, $\mu=$ the overall mean, $\mathrm{CP}_{\mathrm{i}}=$ fixed impact of crude protein levels, $\mathrm{SD}_{\mathrm{j}}=$ fixed impact of stocking density, $\mathrm{CPSD}_{\mathrm{ij}}=$ fixed impact of interaction between $\mathrm{CP}$ and $\mathrm{SD}$ levels and $\mathrm{e}_{\mathrm{ijk}}=$ random error associated to each observation.

\section{RESULTS}

Results of live body weight and daily body weight gain as affected by dietary crude protein levels and stocking density are presented in Table II. It is obvious from the results that live body weight and daily body weight gain during the experimental periods were insignificantly affected by dietary crude protein levels, stocking density and their interactions. Results affirmed the occurrence of insignificant differences in body weight at 2 weeks of age among the different groups, a finding that gives an idea about the accuracy in distributing chicks among the treated feeding groups without any bias.

Results in Table III revealed that dietary crude protein level, stocking density and their interactions did not significantly alter feed consumption, feed conversion ratio and protein efficiency ratio. However, the highest value of protein efficiency ratio (1.19), during 2-10 weeks of age, was observed in ostrich chicks fed diet containing $240 \mathrm{~g} / \mathrm{kg}$, followed by those fed $210 \mathrm{~g} / \mathrm{kg} \mathrm{CP}$ then those fed $180 \mathrm{~g} / \mathrm{kg} \mathrm{CP}$ (1.01). Also, birds fed diet containing $240 \mathrm{~g} / \mathrm{kg} \mathrm{CP}$ and kept at stocking density of $3 \mathrm{~m}^{2}$ per bird had insignificantly the highest protein efficiency ratio in comparison to the other groups (Table III).

Table IV presents the effects of dietary protein levels, stocking density and their interactions on body measurements including body height, tibiotarsus length and tibiotarsus girth. It could be seen that each of shank girth and tibiotarsus length were decreased $(P<0.01)$ with increasing dietary protein level. Where, the highest values of shank girth and tibiotarsus length $(9.1$ and $18.4 \mathrm{~cm}$, respectively) were observed in chicks fed $180 \mathrm{~g} / \mathrm{kg}$ dietary protein level. The other body measurements were not significantly affected due to dietary protein level. Stocking density did not change values of body measurements, except tibiotarsus length at 6 weeks of age, which was increased $(P<0.05)$ in birds kept at $3 \mathrm{~m}^{2} /$ bird. Body height at 10 weeks of age was the exceptional measurement. It was significantly $(P<0.05)$ affected by the interactions among dietary protein levels and stocking density. Birds kept at a lower density and fed higher levels of crude protein had the higher values of body height. 
TABLE II

Live body weight and daily body weight gain of growing ostrich as affected by dietary crude protein levels, stocking density and their interactions.

\begin{tabular}{|c|c|c|c|c|c|c|c|}
\hline \multirow{2}{*}{\multicolumn{2}{|c|}{ Items }} & \multicolumn{3}{|c|}{ Live body weight (g) } & \multicolumn{3}{|c|}{ Daily body weight gain (g/d) } \\
\hline & & 2 wks & $6 \mathrm{wks}$ & $10 \mathrm{wks}$ & 2-6 wks & 6-10 wks & $2-10 \mathrm{wks}$ \\
\hline \multicolumn{8}{|c|}{ CP level } \\
\hline & 180 & 2961 & $6170^{c}$ & 11263 & $114.6^{\mathrm{c}}$ & 181.9 & 148.3 \\
\hline & 210 & 2662 & $6453^{b}$ & 11240 & $135.4^{\mathrm{b}}$ & 171.0 & 153.2 \\
\hline & 240 & 2797 & $7737^{\mathrm{a}}$ & 12921 & $176.5^{\mathrm{a}}$ & 185.1 & 180.8 \\
\hline \multicolumn{8}{|c|}{ Stocking density ( $\mathrm{m}^{2} /$ bird $)$} \\
\hline & 4.5 & 2800 & 6888 & 12049 & 146.0 & 184.4 & 165.2 \\
\hline & 3 & 2814 & 6686 & 11566 & 138.3 & 174.3 & 156.3 \\
\hline \multicolumn{8}{|c|}{ Interaction effect } \\
\hline CP level & Stocking density & & & & & & \\
\hline \multirow{2}{*}{180} & 4.5 & 2960 & 6517 & 11968 & 127.0 & 194.7 & 160.9 \\
\hline & 3 & 2962 & 5824 & 10557 & 102.2 & 169.0 & 135.6 \\
\hline \multirow{2}{*}{210} & 4.5 & 2744 & 6181 & 11737 & 122.8 & 198.4 & 160.6 \\
\hline & 3 & 2580 & 6724 & 10743 & 148.0 & 143.5 & 145.8 \\
\hline \multirow{2}{*}{240} & 4.5 & 2693 & 7964 & 12443 & 188.2 & 160.0 & 174.1 \\
\hline & 3 & 2900 & 7510 & 13399 & 164.7 & 210.3 & 187.5 \\
\hline & SEM & 105.94 & 12.84 & 14.27 & 2.72 & 2.87 & 2.17 \\
\hline \multicolumn{8}{|c|}{ Probabilities: } \\
\hline & PP level & 0.527 & 0.021 & 0.100 & 0.036 & 0.850 & 0.148 \\
\hline & king density & 0.084 & 0.634 & 0.482 & 0.662 & 0.643 & 0.523 \\
\hline $\mathrm{CP} \times s$ & ocking density & 0.203 & 0.455 & 0.334 & 0.426 & 0.153 & 0.502 \\
\hline
\end{tabular}

Means in the same column within each classification bearing different letters are significantly different $(P<0.05)$.

\section{DISCUSSION}

Growth performance traits of ostrich chicks are important for their rearing under different farming conditions and assessing the performance of rearing practices. Results of the present work demonstrated that extra protein consumed by birds could not be productively utilized by ostrich chicks and were probably eliminated via fecal nitrogen as reported in previous publications (Ahmed et al. 2011, Mahrose et al. 2015). However, Bovera et al. (2011) claimed that feed containing 17\% CP was optimum for ostrich chicks at 20 weeks of age and feeding growing ostriches on higher protein levels not only wasteful but also pollute the environment through the excretion of more unutilized nitrogen (Abd El-Hack et al. 2017, 2018). Due to these explanations, growth rate of the ostriches appeared to be influenced by other environmental factors (Deeming and Ayres 1993), such as stocking density. In addition, Bunter (2002) demonstrated that variability in growth rates in ostrich chicks is attributed to general factors such as season, diet, aspects of social behavior and health. Ahmed et al. (2011) reported that ostrich chicks aged between 10 to 14 weeks of age and fed diets containing 22.5 and $17.5 \% \mathrm{CP}$ insignificantly consumed more feed, grew better and were more efficient in converting feed to body weight than birds fed diet containing $12.5 \%$ CP. Carstens et al. (2014) found insignificant 
TABLE III

Feed consumption, feed conversion ratio and protein efficiency of growing ostrich as affected by dietary crude protein levels, stocking density and their interactions.

\begin{tabular}{|c|c|c|c|c|c|c|c|c|c|c|}
\hline \multirow{3}{*}{\multicolumn{2}{|c|}{ Items }} & \multicolumn{3}{|c|}{ Feed consumption (g) } & \multicolumn{3}{|c|}{$\begin{array}{l}\text { Feed conversion ratio } \\
\qquad(\mathrm{g} \text { feed/g gain })\end{array}$} & \multicolumn{3}{|c|}{$\begin{array}{c}\text { Protein efficiency ratio } \\
\text { (Body weight gain/ protein intake) }\end{array}$} \\
\hline & & $2-6$ & $6-10$ & $2-10$ & $2-6$ & $6-10$ & $2-10$ & $2-6$ & $6-10$ & $2-10$ \\
\hline & & wks & wks & wks & wks & wks & wks & wks & wks & wks \\
\hline \multicolumn{11}{|c|}{ CP level } \\
\hline 18 & & 584.8 & 826.6 & 705.7 & 5.4 & 4.7 & 5.1 & 1.23 & 1.17 & 1.16 \\
\hline 21 & & 538.5 & 702.6 & 620.6 & 4.5 & 4.4 & 4.4 & 1.14 & 1.18 & 1.18 \\
\hline 24 & & 522.8 & 785.3 & 654.0 & 3.0 & 4.6 & 3.8 & 1.01 & 1.16 & 1.19 \\
\hline \multicolumn{11}{|c|}{ Stocking density $\left(\mathrm{m}^{2} /\right.$ bird $)$} \\
\hline 4. & & 539.2 & 834.8 & 687.0 & 4.2 & 4.8 & 4.5 & 1.08 & 1.16 & 1.18 \\
\hline 3 & & 558.2 & 708.2 & 633.2 & 4.5 & 4.2 & 4.4 & 1.17 & 1.17 & 1.17 \\
\hline \multicolumn{11}{|c|}{ Interaction effect } \\
\hline \multicolumn{11}{|c|}{ CP level Stocking density } \\
\hline \multirow{2}{*}{180} & 4.5 & 592.8 & 894.5 & 743.6 & 4.7 & 4.7 & 4.7 & 1.23 & 1.21 & 1.21 \\
\hline & 3 & 576.8 & 758.8 & 667.8 & 6.2 & 4.6 & 5.4 & 1.24 & 1.13 & 1.11 \\
\hline \multirow{2}{*}{210} & 4.5 & 487.0 & 760.3 & 623.6 & 4.8 & 4.2 & 4.5 & 1.23 & 1.23 & 1.24 \\
\hline & 3 & 590.1 & 644.9 & 617.5 & 4.1 & 4.5 & 4.3 & 1.06 & 1.12 & 1.13 \\
\hline \multirow{2}{*}{240} & 4.5 & 537.8 & 849.8 & 693.8 & 2.9 & 5.5 & 4.2 & 0.79 & 1.05 & 1.10 \\
\hline & 3 & 507.7 & 720.8 & 614.3 & 3.1 & 3.6 & 3.4 & 1.22 & 1.27 & 1.28 \\
\hline SEM & & 15.73 & 21.92 & 13.23 & 0.41 & 0.49 & 0.35 & 0.31 & 0.26 & 0.26 \\
\hline \multicolumn{11}{|c|}{ Probabilities: } \\
\hline $\mathrm{CP} 1$ & & 1.643 & 10.736 & 9.920 & 0.060 & 0.919 & 0.089 & 0.403 & 0.990 & 0.968 \\
\hline Stocking & ensity & 0.428 & 32.419 & 11.722 & 0.670 & 0.291 & 0.754 & 0.525 & 0.891 & 0.948 \\
\hline $\begin{array}{r}\mathrm{CP} \times \mathrm{St} \\
\mathrm{den}\end{array}$ & $\begin{array}{l}\text { king } \\
\text { y }\end{array}$ & 2.116 & 0.072 & 2.305 & 0.484 & 0.251 & 0.339 & 0.219 & 0.332 & 0.422 \\
\hline
\end{tabular}

differences between the high $(23.48 \% \mathrm{CP})$ and low $(16.8 \% \mathrm{CP})$ diets on body weight gain during the first 7 weeks of age, insignificant differences between the high and medium $(20.28 \% \mathrm{CP})$ diets on body weight gain during the first eleven weeks of age and insignificant differences between the medium and low diets on body weight gain during the first fourteen weeks of age. Our results are similar to those obtained by Brand et al. (2000) who concluded that dietary protein levels $(13,15$ and $17 \%$ ) had no effect on the growth performance of ostrich chicks during 16 to 44 weeks of age. Gandini and Burroughs (1986) showed comparable results, where ostrich chicks, aged up to 8 weeks of age, fed diets of different protein levels (14,
16, 18 and 20\%), no differences were found in growth performance among diets with 16,18 or $20 \%$ protein, while birds on these diets performed better compared to those on a $14 \%$ protein diet and those received 20\% CP showed the superior feed conversion. Vahabi-Asil et al. (2017) assured that dietary protein level had a significant effect on body weight gain and feed conversion ratio of turkeys during the finisher phase.

In the present work, the best ratio of feed conversion (3.8 $\mathrm{g}$ feed / g gain) was seen in the group of chicks that fed on $180 \mathrm{~g} / \mathrm{kg} \mathrm{CP}$ diet during the whole period (2-10 weeks of age). The average of the feed conversion ratio from hatch to 9 months of ostrich age ranges from 3.6 to 3.9 (Bunter 


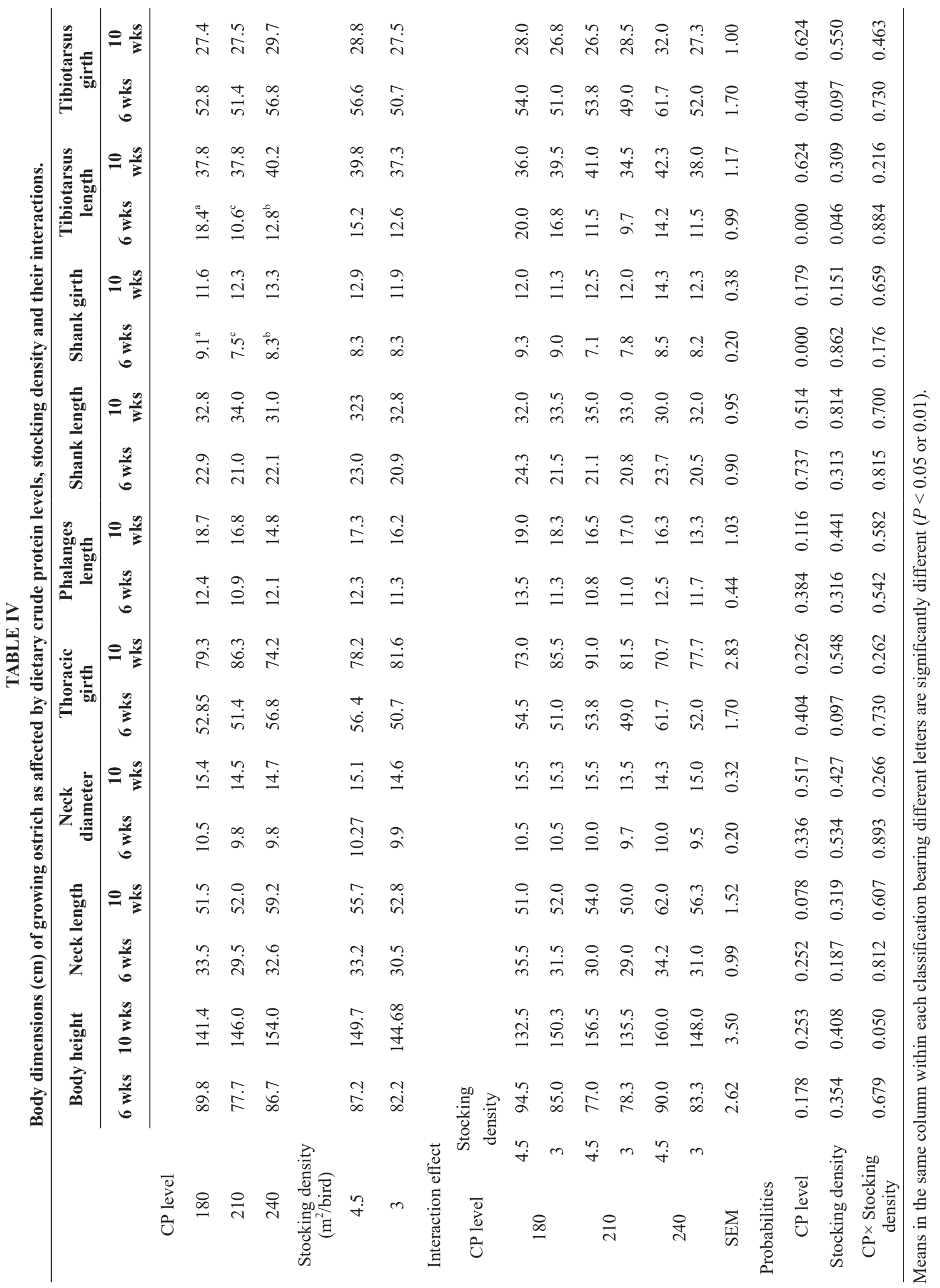


2002), so our results are in that range. Ahmed et al. (2011) indicated that ostrich chicks during 10-14 weeks of age fed diets containing 22.5 or $17.5 \%$ $\mathrm{CP}$ consumed more feed and were more efficient in converting feed than birds fed diets containing $12.5 \% \mathrm{CP}$. However, the later author added that the differences between the two diets contained 22.5 and $17.5 \% \mathrm{CP}$ were inconsistent and not significant on feed consumption and feed conversion ratio. The inability of the digestive tract of the ostrich chicks to secrete trypsin immediately after hatching constitutes a major difference between this species and broiler chickens (Iji 2005). This suggests that utilization of dietary protein during early life will be less efficient in the ostrich than in poultry. Commercial diets for ostriches are still based on poultry formulations, but it is unlikely that the high levels of dietary protein used in broiler chicken diets will be efficiently utilized by the neonatal ostrich. The activity of amylase is low and remains relatively unchanged from hatch until 72 days of age (Mahrose et al. 2015).

Amado et al. (2011) indicated that ostrich chicks walked and ran more than when they were older. In turn, it means that ostrich chicks may need more space to show their behavior and grow better. Space requirements for ostriches vary slightly according to type of accommodation. However, from a welfare point of view, $0.5 \mathrm{~m}^{2}$ of floor space per bird during the first three weeks is generally recommended, increasing to $0.7 \mathrm{~m}^{2}$ up to five weeks. From about five weeks of age (depending on weather conditions), the chicks should be allowed out for about one hour daily (Shanawany and Dingle 1999). In this regard, in the study carried out by Degen et al. (1991), ostrich chicks were kept at stocking density of $1 \mathrm{bird} / \mathrm{m}^{2}$. Overcrowding during the brooding and rearing stages can lead to slow growth rates. In an experiment conducted by Cornetto et al. (2003) on ostrich chicks aged between 21 to 98 days, they found that there were significant differences in body weight gain only during 28 to 56 days of age, where ostrich chicks kept in the lower stocking density $\left(33.5 \mathrm{~m}^{2} /\right.$ bird $)$ had the higher body weight gain. However, they did not find significant changes in feed conversion ratio due to stocking density, but they concluded that the stocking density of $16 \mathrm{~m}^{2}$ per bird was found to maximize chicks' performance. In our study, feed conversion ratios were higher than what was reported by the latter author. In line, Bouyeh et al. (2017) found no significant impact for stocking density on productive and reproductive performance of ostriches.

Measuring body dimensions could be a useful tool to estimate body weight and the area of the skin (Bezuidenhout and Schalkwyk 1996, Deeming et al. 1996, Ali 2004) that is a way to predict profit at marketing and to solve one of the main problems in ostrich trading, which is the cheating in age or weight of chicks in some areas. Body condition of ostriches is very important to avoid obesity and loss of weight is an important indicator of malnutrition (Deeming et al. 1996). The same author added that the body measurements are important in aiding the calculation of dosage of medications. The later authors added that tibiotarsus length in growing ostriches up to sub-adults (less than two years of age) ranged from 10 to $64 \mathrm{~cm}$. Mushi et al. (1998) pointed out that the average of body height rapidly increased reaching $134 \mathrm{~cm}$ in the $16^{\text {th }}$ week, and this is very close to what is reported in the present study with taking age into consideration. Body measurements in the present study are higher than those reported by Ali (2004) at 75 days of age.

The results of the present study indicated that ostrich chicks (during 2-10 weeks of age) could grow on diets containing low levels of CP (180$210 \mathrm{~g} / \mathrm{kg}$ ). The present study suggested the needs for further research on the protein requirements for ostrich. Also, our results imply that space availability for ostrich chicks during 2-10 weeks of age can influence their performance. Results of the present work provide a comprehensive set of 
morphometric data for ostrich chicks during 2-10 weeks of age as affected by dietary protein level, stocking density and their interactions, which could be useful for the breeders.

\section{ACKNOWLEDGMENTS}

The authors would like to thank Zagazig University for the logistic support they received.

\section{AUTHOR CONTRIBUTIONS}

Khalid Mahrose and Mohamed Abd El-Hack designed the study plan, collected literature, and drafted the manuscript. Shymaa Amer helped in conducting research work. Khalid Mahrose provided technical help in the write-up of this manuscript. Khalid Mahrose and Mohamed Abd ElHack reviewed and performed the final check. All the authors read and approved the final manuscript.

\section{REFERENCES}

ABD EL-HACK ME, EL-HINDAWY MM, ATTIA AI AND MAHROSE KM. 2017. Does the use of distiller's dried grains with solubles (DDGS) in layer diets affect the nutrients digestibility and manure pollution by nitrogen and phosphorous?. Environ Sci Poll Res 24(15): 1333513343.

ABD EL-HACK ME, NORELDIN AE, MAHGOUB SAAND ARIF M. 2018. Ways to Minimize Nitrogen Emissions in Agricultural Farms. In: Negm A and Abu-Hashim M (Eds), Sustainability of Agricultural Environment in Egypt: Part II: Soil-Water-Plant Nexus (The Handbook of Environmental Chemistry), vol. 77, Springer, Cham, p. 357-368.

AHMED E, AZAHAN E AND NORAZIAH M. 2011. Evaluation of dietary protein intake by growing ostriches. Asian J Poult Sci 5: 102-106.

ALAGAWANY M, ABD EL-HACK ME, ARIF M AND ASHOUR EA. 2016a. Individual and combined effects of crude protein, methionine, and probiotic levels on laying hen productive performance and nitrogen pollution in the manure. Environ Sci Pollu Res 23(22): 22906-22913.

ALAGAWANY M, ABD EL-HACK ME, FARAG MR, TIWARI R, SACHAN S, KARTHIK K AND DHAMA K. 2016b. Positive and negative impacts of dietary protein levels in laying hens. Asian J Anim Sci 10: 165-174.
ALAGAWANY M, ABD EL-HACK ME, LAUDADIO V AND TUFARELLI V. 2014. Effect of low-protein diets with crystalline amino acid supplementation on egg production, blood parameters and nitrogen balance in laying Japanese quails. Avian Biol Res 7(4): 235-243.

ALI SYA. 2004. Genetical and physiological studies of some productive traits in ostrich (Struthio camelus). M.Sc. Thesis, Faculty of Agriculture. Minufiya University, Shibin El-Kom, Egypt. (Unpublished).

AMADO MF, XAVIER DB, BOERE V, TORRES-PEREIRA C, MCMANUS C AND BERNAL FEM. 2011. Behaviour of captive Ostrich chicks from 10 days to 5 months of age. Rev Brasil Zootec 40: 1613-1618.

BEZUIDENHOUT AG AND SCHALKWYK SJV. 1996. Improving our understanding of ratites in a farming environment. In: Deeming DC (Ed), Ratite Conference, $5 \mathrm{p}$.

BOUYEH M, SEIDAVI AR, MOHAMMADI H, SAHOO A, LAUDADIO V AND TUFARELLI V. 2017. Effect of climate region and stocking density on ostrich (Struthio camelus) productive performances. Reprod Domest Anim 52(1): 44-48.

BOVERA F, MARONO S, DI MEO C, IANNACCONE F, ATTIA Y AND NIZZA A. 2011. Comparison of caecal and faeces fermentation characteristics of ostrich by in vitro gas production technique. Acta Agric Scand Section A-Anim Sci 61: 72-79.

BRAND T, NELL C AND VAN SCHALKWYK S. 2000. The effect of dietary energy and protein level on the production of growing ostriches. South African J Anim Sci 30: 15-16.

BUNTER K. 2002. The genetic analysis of reproduction and production traits recorded for farmed ostriches (Struthio camelus). PhD thesis, University of New England, Armidale. (Unpublished).

CARSTENS P, SHARIFI A, BRAND T AND HOFFMAN L. 2014. The growth response of ostrich (Struthio camelus var. domesticus) chicks fed on diets with three different dietary protein and amino acid concentrations. Br Poult Sci 55: 510-517.

CILLIERS S. 1998. Feedstuff evaluation, metabolisable energy and amino acid requirements for maintenance and growth in ostriches. 2. International Scientific Ratite Congress. Ratites in a competitive world, Oudtshoorn (South Africa), 21-25 Sep 1998. Dept. of Agriculture Western Cape. (Unpublished).

CILLIERS S, HAYES J, CHWALIBOG A, SALES J AND DU PREEZ J. 1998. Determination of energy, protein and amino acid requirements for maintenance and growth in ostriches. Anim Feed Sci Technol 72: 283-293.

COOPER RG. 2004. Ostrich (Struthio camelus) chick and grower nutrition. Anim Sci J 75: 487-490. 
COOPER RG, ERLWANGER K AND MAHROZE KM. 2005. Nutrition of ostrich (Struthio camelus var. domesticus) breeder birds. Anim Sci J 76: 5-10.

COOPER RG, MAHROSE KM, EL-SHAFEI M AND MARAI IF. 2008. Ostrich (Struthio camelus) production in Egypt. Tropic Anim Health Prod 40: 349-55.

CORNETTO T, ANGEL R AND ESTEVEZ I. 2003. Influence of stocking density and dietary energy on ostrich (Struthio camelus) performance. Inter J Poult Sci 2: 102-106.

DEEMING D AND AYRES L. 1993. Factors affecting the rate of growth of ostrich (Struthio camelus) chicks in captivity. Vet Rec 135: 617-622.

DEEMING D, SIBLY R AND MAGOLE I. 1996. Estimation of the weight and body condition of ostriches (Struthio camelus) from body measurements. Vet Rec 139: 210-213.

DEGEN A, KAM M, ROSENSTRAUCH A AND PLAVNIK I. 1991. Growth rate, total body water volume, dry-matter intake and water consumption of domesticated ostriches (Struthio camelus). Anim Sci 52: 225-232.

DU PREEZ J. 1991. Ostrich nutrition and management. In: Farrel DJ (Ed), Recent Advances in Animal Nutrition in Australia. University of New England, Armidale, Australia, p. 278-291.

DUNCAN DB. 1955. Multiple range and multiple F tests. Biometrics 11: 1-42.

EL-SAFTY S AND MAHROSE KM. 2009. Evaluation of some phenotypic, physiological and egg quality traits of african black neck ostrich under arid desert conditions of Libya. Inter J Poult Sci 8: 553-558.

GANDINI H AND BURROUGHS G. 1986. Preliminary investigation into the nutrition of ostrich chicks (Struthio camelus) under intensive conditions. J South African Vet Assoc 57: 39-42.

IJI P. 2005. Anatomy and digestive physiology of the neonatal ostrich (Struthio camelus) in relation to nutritional requirements. Recent Adv Anim Nutr 15: 165-170.

LAUDADIO V AND TUFARELLI V. 2011. Influence of substituting dietary soybean meal for dehulled-micronized lupin (Lupinus albus cv. Multitalia) on early phase laying hens production and egg quality. Livest Sci 140: 184-188.

MAHROSE K, ELSAYED M, BASUONY H AND GOUDA N. 2016. Effects of exposing ostrich eggs to doses of gamma radiation on hatchability, growth performance, and some blood biochemicals of hatched chicks. Environ Sci Poll Res 23: 23017-23022.

MAHROSE KM, ATTIA A, ISMAIL I, ABOU-KASSEM D AND ABD EL-HACK ME. 2015. Growth performance and certain body measurements of ostrich chicks as affected by dietary protein levels during 2-9 weeks of age. Open Vet J 5: 98-102.

MINKA N. 2004. Evaluation of the performance of farmed ostrich chicks to juvenile age in Northern Nigeria. Nigerian J Anim Sci 6: 1.

MUSHI EZ, ISA JF, CHABO RG AND SEGAISE TT. 1998. Growth rate of ostrich (Struthio camelus) chicks under intensive management in Botswana. Tropic Anim Health Prod 30: 197-203.

REDA FM, ASHOUR EA, ALAGAWANY M AND ABD EL-HACK ME. 2015. Effects of dietary protein, energy and lysine intake on growth performance and carcass characteristics of growing Japanese quails. Asian J Poult Sci 9(3): 155-164.

REHMAN ZU, KAMRAN J, ABD EL-HACK ME, ALAGAWANY M, BHATTI SA, AHMAD G, SALEEM A, ULLAH Z, YAMEEN RMK AND DING C. 2018. Influence of low-protein and low-amino acid diets with different sources of protease on performance, carcasses and nitrogen retention of broiler chickens. Anim Prod Sc 58(9): 1625-1631.

SHANAWANY MM AND DINGLE JH. 1999. Ostrich production systems. Food and Agriculture Organization, $144,256 \mathrm{p}$.

SIGOLO S, ZOHRABI Z, GALLO A, SEIDAVI A AND PRANDINI A. 2017. Effect of a low crude protein diet supplemented with different levels of threonine on growth performance, carcass traits, blood parameters, and immune responses of growing broilers. Poult Sci 96(8): 2751-2760.

VAHABI-ASIL O, BOUYEH M, QOTBI A, KADIM IT, SEIDAVI A, CENTODUCATI G, LAUDADIO V AND TUFARELLI V. 2017. Effects of a prebiotic on growth performance, blood parameters and immunity response of turkeys fed low protein diets. European Poult Sci 81: 1-12.

VERWOERD DJ. 1999. Rearing environments around the world. The ostrich: Biology, production and health, p. 191216. 